\title{
Tourism Village Carbon Footprint after COVID-19 Pandemic: A Challenge to Sustainability
}

\author{
Rr. M. I. Retno Susilorini ${ }^{1, *(1)}$, Amrizarois Ismail ${ }^{1}$, B. Y. Arya Wastunimpuna ${ }^{1}$, Dhiyan Krishna Wardhani ${ }^{1}$, \\ Laurel Lia Nola Prameswari ${ }^{1}$, Ardhito Hayyu Amasto ${ }^{1}$ and Agus Suryono ${ }^{2}$
}

1 Department of Infrastructure and Environmental Engineering, Faculty of Environmental Sciences and Technology, Soegijapranata Catholic University, Semarang 50234, Indonesia; amrizarois@unika.ac.id (A.I.); arya_wastunimpuna@unika.ac.id (B.Y.A.W.); dhiyan.krishna@unika.ac.id (D.K.W.); 19o30001@student.unika.ac.id (L.L.N.P.); 19O30005@student.unika.ac.id (A.H.A.)

2 AKSI (Asosiasi Klaster Indonesia, Indonesian Cluster Association), Business Incubator, Semarang 50264, Indonesia; agussuryono@inkubatoraksi.com

* Correspondence: susilorini@unika.ac.id; Tel.: +62-24-8505003

check for

updates

Citation: Susilorini, R.M.I.R.; Ismail, A.; Wastunimpuna, B.Y.A.; Wardhani, D.K.; Prameswari, L.L.N.; Amasto, A.H.; Suryono, A. Tourism Village Carbon Footprint after COVID-19 Pandemic: A Challenge to Sustainability. Sustainability 2022, 14 , 2400. https://doi.org/10.3390/ su14042400

Academic Editor: Silvia Fiore

Received: 9 January 2022

Accepted: 16 February 2022

Published: 19 February 2022

Publisher's Note: MDPI stays neutral with regard to jurisdictional claims in published maps and institutional affiliations.

Copyright: (C) 2022 by the authors. Licensee MDPI, Basel, Switzerland. This article is an open access article distributed under the terms and conditions of the Creative Commons Attribution (CC BY) license (https:/ / creativecommons.org/licenses/by/ $4.0 /)$.

\begin{abstract}
The tourism industry is the most significant global Green House Gases (GHGs) contributor, which is often specifically produced by exploratory activities. This leads to the performance of several actions to reduce carbon emissions and maintain sustainable development. Since the Indonesian Tourism Village is a "carbon emission contributor and COVID-19 pandemic impact victim", the lowcarbon exploration should be necessarily implemented to achieve sustainability. Therefore, this study aims to determine the carbon footprint of solid waste produced by visitors, population, and buildings within seven certified Tourism Villages in Central Java (Kandri, Lerep, Samiran, Karangrejo, Candirejo, Samiran, and Dieng Kulon) and Special Region of Yogyakarta (Pentingsari) Provinces, Indonesia. This was conducted through a mixed method containing quantitative and analytical techniques. The quantitative method was conducted through a field survey of seven Tourism Villages to obtain and analyze data on the population, infrastructures, situations, and environments. Meanwhile, the analytical method was conducted by calculating the carbon footprint of solid waste and buildings produced by seven Tourism Villages. The results showed that Dieng Kulon had the biggest $\mathrm{CO}_{2}$ emissions from all sources (solid waste produced by visitors, population, and buildings). In addition, Candirejo had the lowest solid waste emission produced by visitors and the population before the impact of the pandemic. During the COVID-19 period, Kandri and Samiran were observed as the lowest contributors of solid-waste $\mathrm{CO}_{2}$ emission produced by visitors and buildings, respectively. This indicated that the sustainability of Tourism Villages helped in increasing income as well as obtaining a cleaner and healthier environment. After the pandemic period, these villages should subsequently lead the economic recovery of rural communities to achieve sustainable development goals through the reduction of $\mathrm{CO}_{2}$ emission. In addition, the "The Low-Carbon Sustainable Tourism Village Model" was proposed by this study to answer the challenge of sustainability.
\end{abstract}

Keywords: tourism village; carbon footprint; $\mathrm{CO}_{2}$ emission; solid waste; building; COVID-19; sustainability

\section{Introduction}

Climate change has been a devastating phenomenon over two centuries, as reported by the IPCC (Intergovernmental Panel on Climate Change) [1], which stated that the global surface temperature alteration was averaged at $0.99^{\circ}$ between $1850-1900$, with a $0.5^{\circ}$ increase also observed until 1950. However, a significant increase from $1.09-1.3^{\circ}$ was observed between 2011-2020, due to the contribution of GHGs (Green House Gases), specifically $\mathrm{CO}_{2}$, and aerosols. This indicates that climate change has threatened global cultures, lands, and livelihoods [2]. Therefore, action should be initiated to promote 
climate change and disaster risk reduction, as well as decrease the emission of $\mathrm{CO}_{2}$ for sustainable development.

The minimization of climatic change impacts is found to be very necessary, specifically $\mathrm{CO}_{2}$ emission reduction and implementation of a low-carbon footprint policy. Furthermore, several global agreements have been ratified in responding to these impacts, such as the Sendai Framework for Disaster Risk Reduction (March 2015; UNISDR 2015), Paris Agreement (United Nations Framework Convention on Climate Change, UNFCCC, 2015), and the SDGs (Sustainable Development Goals) agreed upon by 193 countries (UNGA 2015). These global policy agreements have helped in strengthening all countries to prepare, adapt, and mitigate the impact of climate change towards sustainable development goals [3]. One of several countries with a strong climatic change commitment is the Republic of Indonesia, due to the signing of the Kyoto Protocol (ratified on 3 December 2004) and the Paris Agreement (ratified on 31 October 2016) on 13 July 1998 and 22 April 2016, respectively. The role of this country in the global climatic forum is also represented by hosting the 13th Conference of Parties (COP-13), which was held in Bali on 3-4 December 2007. Moreover, several laws and regulations have been stipulated by the Indonesian Government, to implement the policy of climate change. These included Law No. 6/1994 (ratified the United Nations Framework Convention on Climate Change), Law No. 17/2004 (ratified the Kyoto Protocol and the UN Framework Convention on Climate Change), and Law No. 16/2016 (ratification of the Paris Agreement to the United Nations Framework Convention on Climate Change).

The tourism industry plays an important role in climate change, based on being a "carbon emission contributor and victim of the COVID-19 pandemic impact". As an "actor of carbon emission contributor", this industry has significantly contributed to GHGs (Green House Gases) on a global scale. This was in line with $[4,5]$, which stated that an increase was observed within the tourism's global carbon footprint, between 3.9-4.5 $\mathrm{GtCO}_{2}$ emission in 2009-2013 (approximately 8\% of global GHGs). Since this emission is being produced by tourism activities, several reduction actions should be implemented in maintaining sustainable development towards a low-carbon economy [6]. This economy has been developed towards a new concept of low-carbon tourism based on sustainability [7-10]. The carbon footprint of tourism is known as the direct emission of exploratory activities and embodiments within the tourists' purchased commodities, such as transportation, fuel, food, accommodation (hotels, guest houses, homestays, etc.), dining, recreational programs, souvenirs, and shopping [4,5]. Based on previous studies [11-13], a significant volume of $\mathrm{CO}_{2}$ emission was produced by the tourist attractions within the heritage sites of Yogyakarta Special Region in Indonesia, as well as the Wulingyuan Scenic/Historic Interest Area (WSHIA) and Guizhou ethnic locations in China.

According to the UNWTO Barometer (September 2021), the pandemic played a 'role' in tourism as a "victim of COVID-19 impact", which greatly and globally suffered in the exploratory industry [14]. This indicated that global international tourist arrivals (overnight visitors) until July 2021 were $40 \%$ below the levels of 2020 , which was $80 \%$ lower still compared to the similar pre-pandemic period in 2019. In addition, the pandemic affected the arrival of tourists, which declined $74 \%$ of approximately 1 billion trips within JanuaryDecember 2020 [15]. The UNWTO subsequently stated that the impact of the COVID-19 pandemic affected "all parts of its vast value-chain," such as global economies, livelihoods, public services, and opportunities, respectively [16]. Therefore, tourism export revenues have reportedly declined to $\$ 910$ billion from $\$ 1.2$ trillion in 2020, which also reduced the global GDP from 1.5-2.8\%. Based on several studies [17-22], the solid waste management produced by tourism activities has been investigated, as well as its carbon footprint and reduction strategies. This indicated that tourist activities had contributed $41.9-46.6 \%$ of solid waste generation per resident in Madeira Island, Portugal [18], and subsequently produced $48.21 \%$ of organic pollutants in the Nusa Penida Islands, Indonesia [20]. According to [19], proper waste management was analyzed in the tourism area of Coachella Valley, California, USA, although the distinctions between the pollutant administration 
in rural and urban areas were still very important, specifically in exploratory regions [21]. These studies showed that tourism activities should be adequately managed in producing low-carbon solid waste.

Among the contributors of global GHGs, buildings are found to have highly contributed to the crisis of climate change, specifically the 'embodied' emissions from the manufacturing and processing of construction materials, as reported by [23]. This study indicated that the average share of embodied GHG was approximately $20-25 \%$ of life cycle emissions. Based on the UN Environment Program [24], the direct energy-related emissions observed from buildings was approximately $6.9 \mathrm{GtCO}_{2}$ in 2019. However, both direct and indirect emissions were observed at $10 \mathrm{GtCO}_{2}$ in the same year (approximately $28 \%$ of total global $\mathrm{CO}_{2}$ emissions). The manufacture, transportation, and utilization of all construction materials also contributed to $\mathrm{CO}_{2}$ emissions at approximately $3.5 \mathrm{GtCO}_{2}$ in 2019 (10\% of all energy sector emissions). According to [25], the building's life cycle related to energy consumption contained several stages, namely: planning and designing, material preparations, construction, operational maintenance, and dismantlement. Among these stages, the operational maintenance and material preparations highly contributed to the emission of $\mathrm{CO}_{2}$ at 78.05 and $20.59 \%$, respectively.

The tourism industry in Indonesia (specifically Tourism Villages) is reportedly affected by the COVID-19 pandemic, due to the decline and low demand of tourist arrivals and sectors, as well as the closure of exploratory, attractive, and entertainment sites, respectively. The impact of this pandemic is found to be devastating for rural communities, specifically Tourism Villages, leading to the necessary implementation of low-carbon exploratory activities to achieve sustainability. This has happened because the tourism activities limitation by regulation during the COVID-19 pandemic made the Tourism Villages have low or even zero visitors and activities. The low tourism activities in Tourism Villages produced a low carbon footprint that is a 'blessing in disguise'. However, the gradual growth of the tourism industry during the post-pandemic period is optimistically achieved.

Since the carbon emission contribution of the tourism industry becomes greater year to year, it is important to reduce carbon footprints of Tourism Villages, especially the seven Tourism Villages considered in this study as the most popular and certified Tourism Villages in Central Java Province and Special Region of Yogyakarta Province. A total of six villages (Kandri, Lerep, Samiran, Karangrejo, Candirejo, Samiran, and Dieng Kulon) are located in Central Java, with only one (Pentingsari) in the Special Region of Yogyakarta. All these sites are found to be certified as "Sustainable Tourism Villages" by the local government, with some also being provided with several prestigious international awards. However, the concept of low-carbon sustainable tourism village have not been fully implemented yet.

It is also obvious that the COVID-19 pandemic has an impact of zero or very low visitor arrivals of those seven Tourism Villages. Hence, this study aimed to determine the carbon footprint of the Tourism Village which is produced by several exploratory activities, specifically in the utilization of energy in construction, building operation and maintenance, etc. Carbon footprints of the seven Tourism Villages are mostly contributed by the visitors and the buildings' operation and maintenance; therefore, it is important to calculate the carbon emissions before and after the COVID-19 pandemic produced by the visitors and buildings. The carbon footprints of the Tourism Villages have to be analyzed and a suitable model obtained for the future of Tourism Villages to have good economic impact as well as green and sustainable characteristics as advantages. A lowcarbon sustainable Tourism Village will be implemented in the model proposed in this research, the "Low-Carbon Sustainable Tourism Village Model", which aimed to reduce the carbon footprint of exploratory sites and solve the challenges of global sustainability.

\section{Methods}

This study was conducted through a mixed method containing both quantitative and analytical techniques. The quantitative method was implemented through the field survey and data analysis of seven Tourism Villages (Kandri, Lerep, Samiran, Karangrejo, Candi- 
rejo, Samiran, Dieng Kulon, Pentingsari), as shown in Figures 1 and 2. This survey was conducted to obtain data on the population, infrastructures, situations, and environments of Tourism Villages. Meanwhile, the analytical method was conducted by calculating the carbon footprint of buildings and the solid waste produced by these villages, as shown in Equation (1) [26],

$$
E_{c}=E F \times V
$$

where,

$E_{c}=$ Carbon emission of solid waste $\left(\mathrm{kg} \mathrm{CO}_{2} / \mathrm{kg}\right)$

$E F=$ Emission Factor of solid waste

$V=$ Solid waste volume

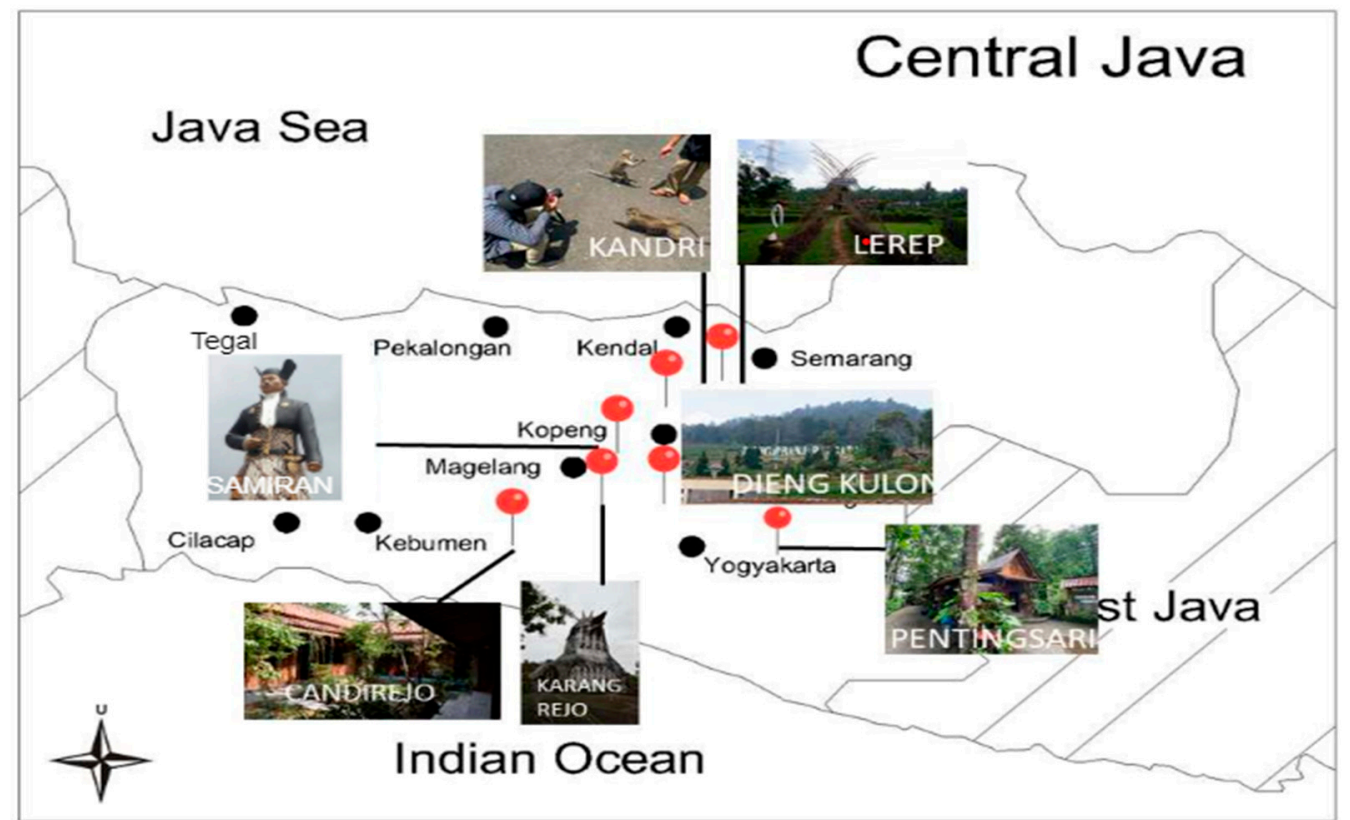

Figure 1. Location of seven Tourism Villages (Kandri, Lerep, Samiran, Karangrejo, Candirejo, Samiran, Dieng Kulon, Pentingsari) in Central Java and Yogyakarta Special Region Provinces, Indonesia.
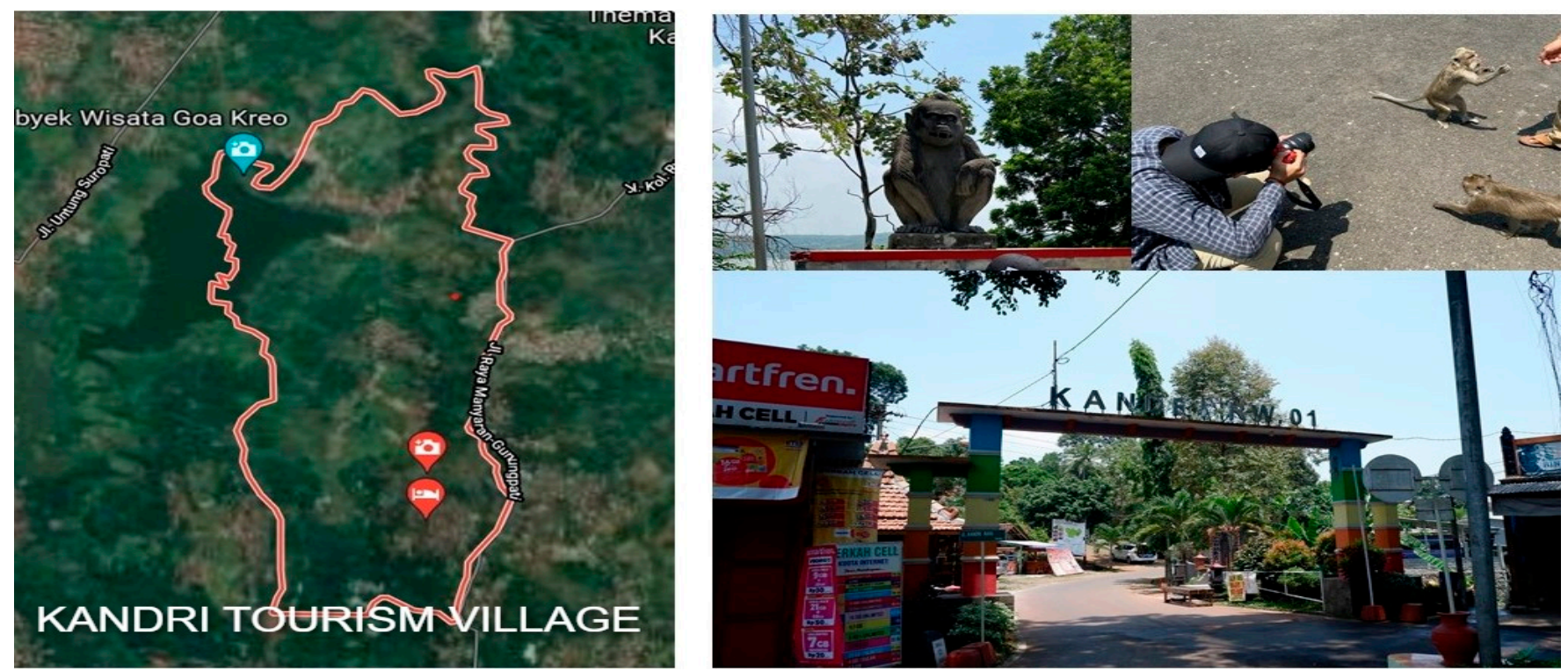

(a)

Figure 2. Cont. 

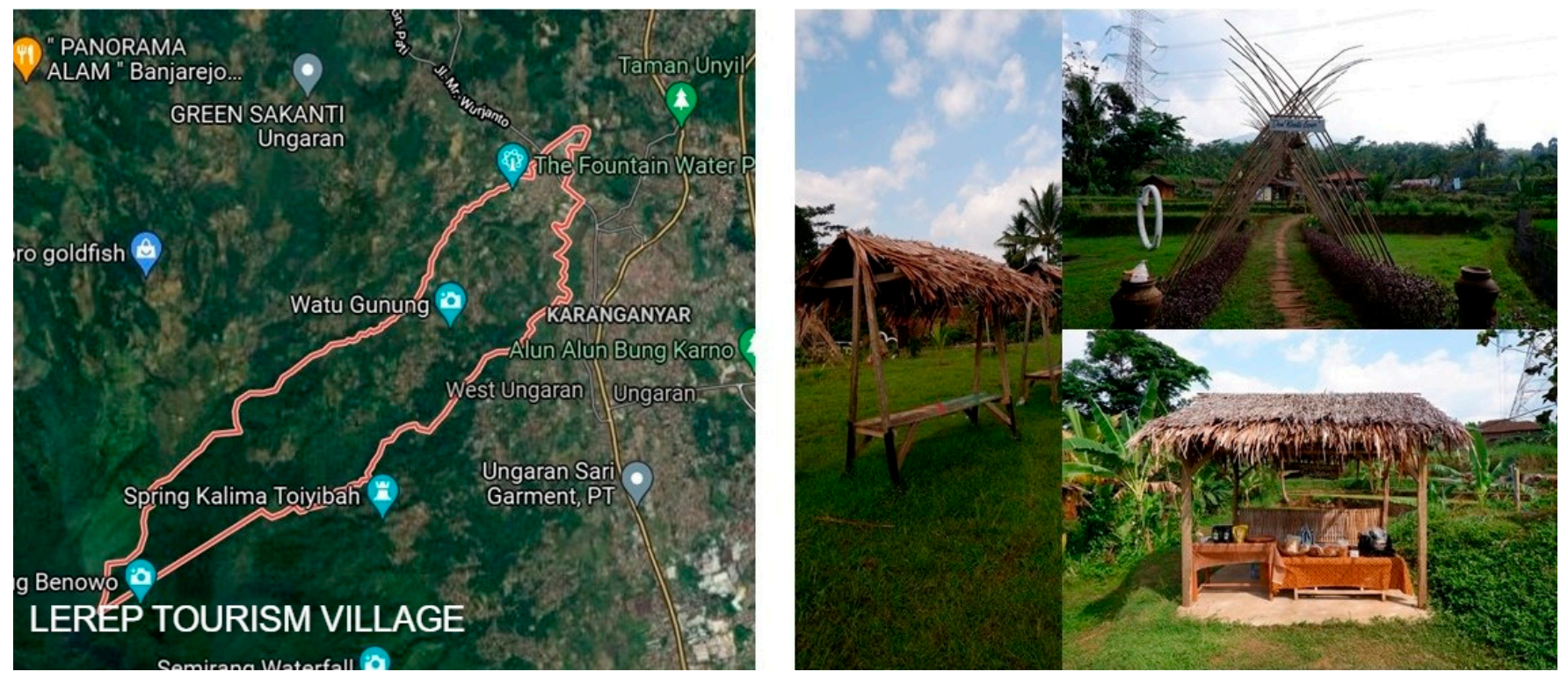

(b)
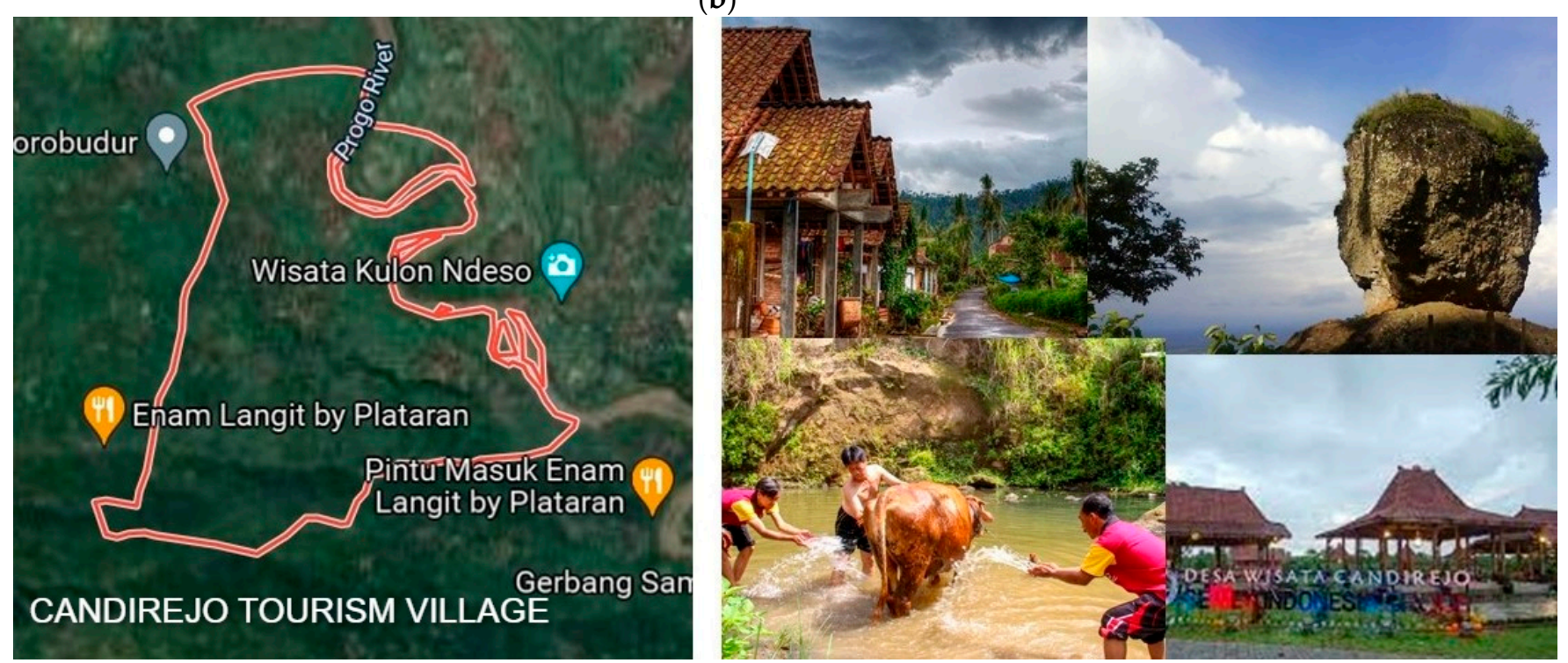

(c)
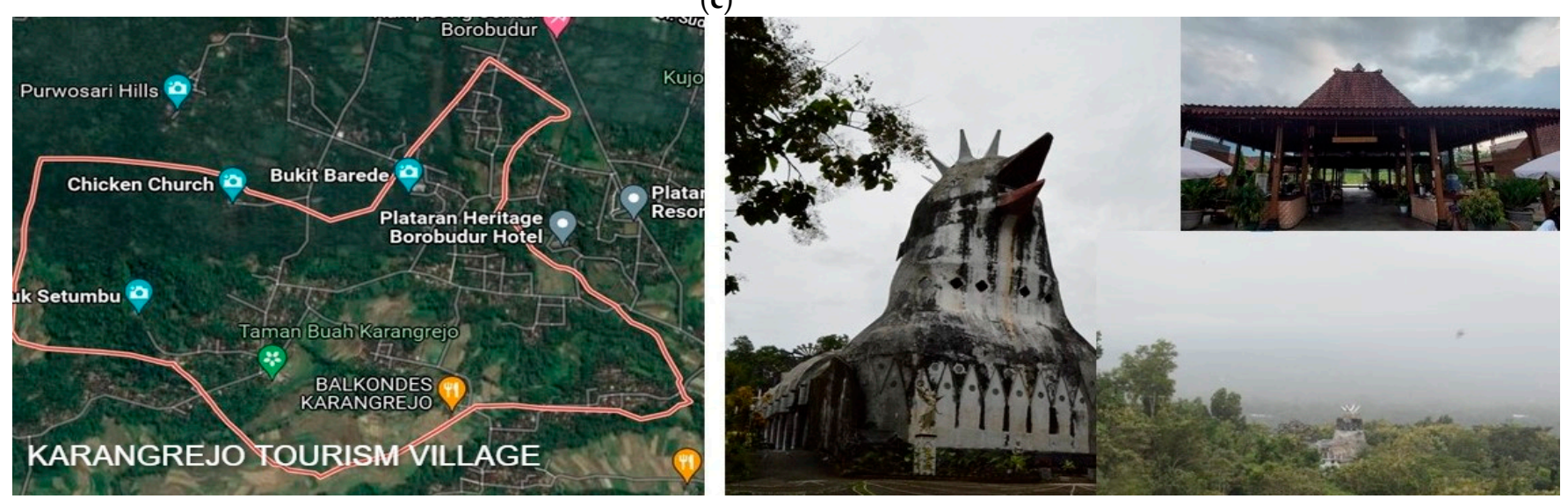

(d)

Figure 2. Cont. 

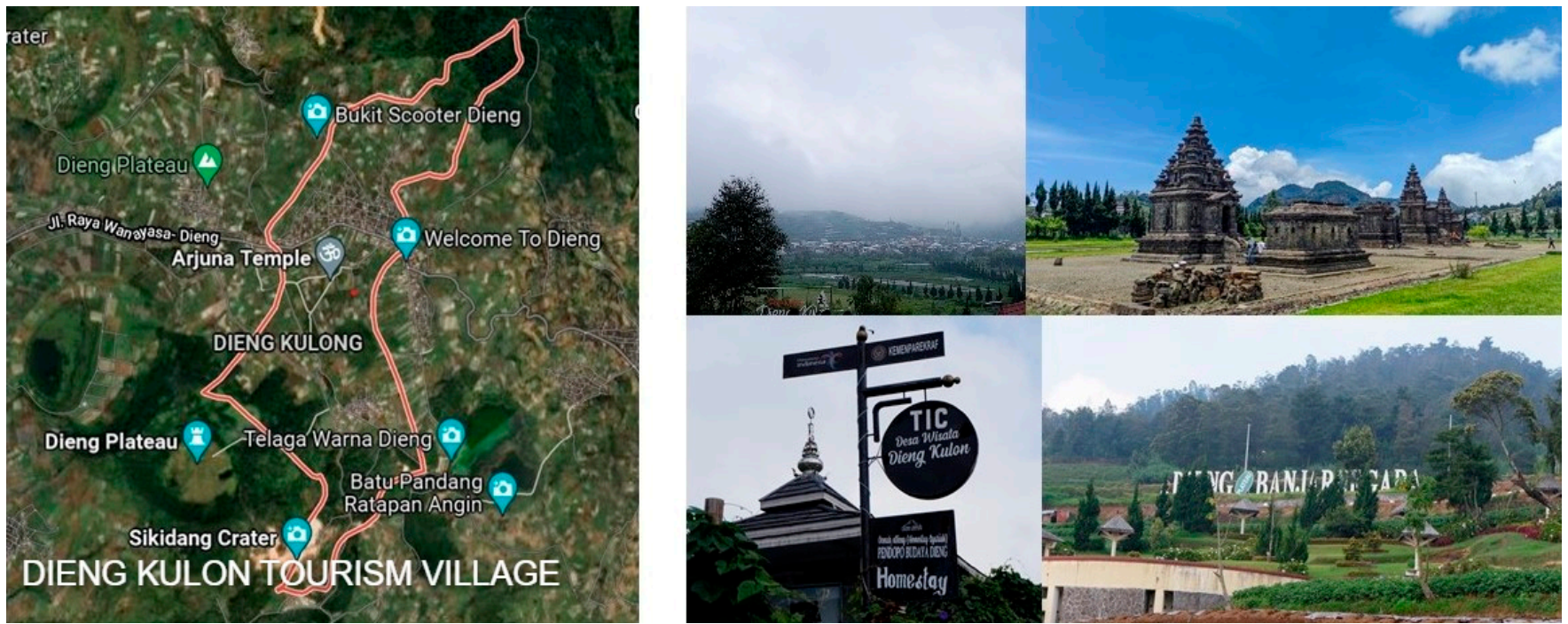

(e)
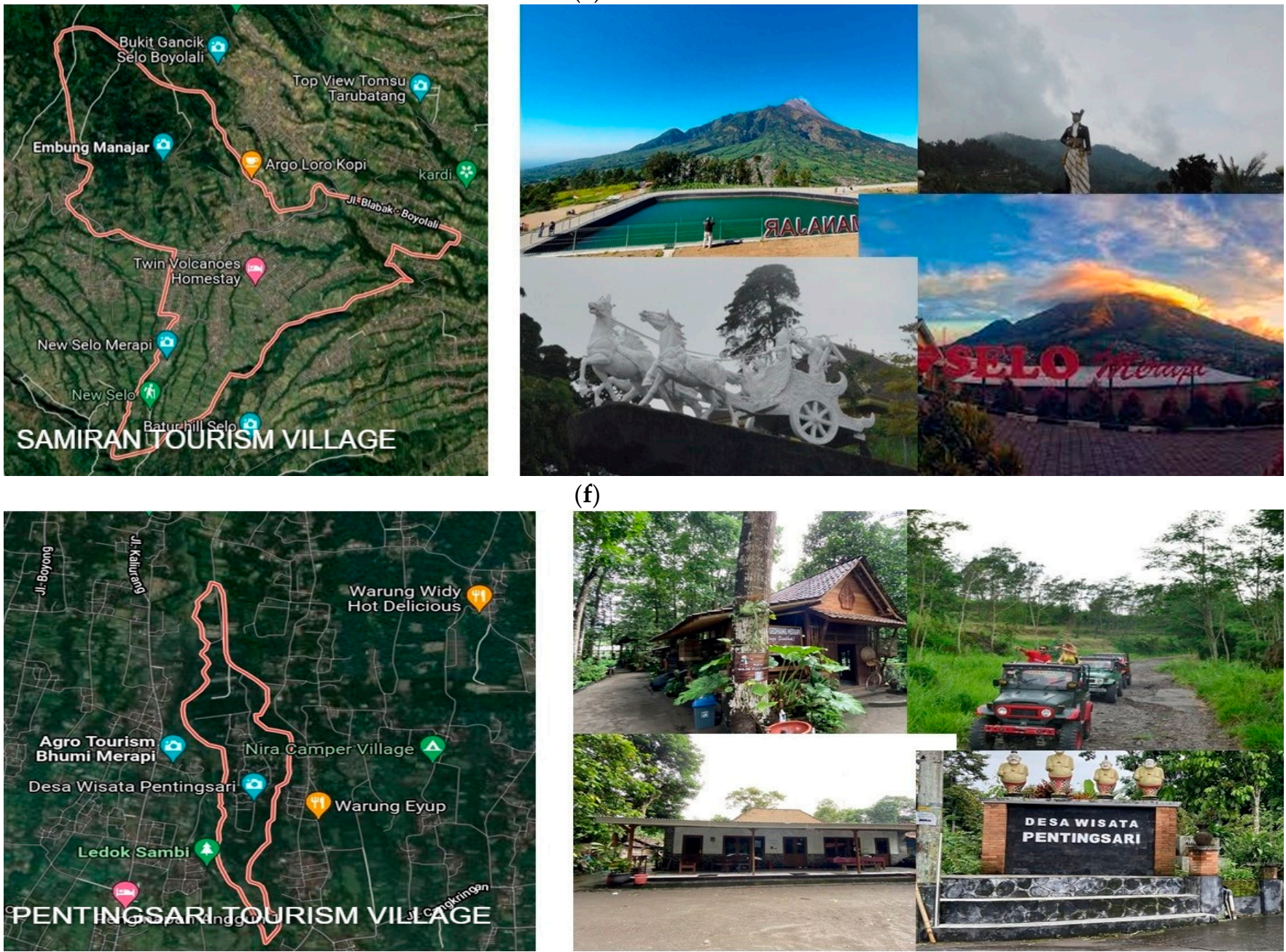

$(\mathrm{g})$

Figure 2. The seven Tourism Villages; (a) Kandri, (b) Lerep, (c) Karangrejo, (d) Candirejo, (e) Samiran, (f) Dieng Kulon, and (g) Pentingsari.

Based on [27,28], Emission Factor (EF) for household and individual solid wastes are shown in Tables 1 and 2, respectively. 
Table 1. Emission Factor for household solid waste based on research of [27].

\begin{tabular}{cc}
\hline Subject & Emission Factor \\
\hline Rural-Household-Solid Waste-Inorganic & 0.668 \\
Rural-Household-Solid Waste-Organic & 0.45 \\
\hline
\end{tabular}

Table 2. The daily solid waste production per person based on research of [28].

\begin{tabular}{ccc}
\hline Solid Waste & $\begin{array}{c}\text { Production per Person per } \\
\text { Day (kg) }\end{array}$ & $\begin{array}{c}\text { Production per Person per Month } \\
\text { (30 Days) (kg) }\end{array}$ \\
\hline Food & 0.0232 & 0.696 \\
Paper & 0.0753 & 2.259 \\
Plastic & 0.0662 & 1.986 \\
Organic & 0.3305 & 9.915 \\
\hline
\end{tabular}

Based on [23], the carbon emission of buildings for seven Tourism Villages was calculated using Equation (2).

$$
E_{c}=E_{e m} \times A
$$

where,

$E_{c}=$ Carbon emission of the building $\left(\mathrm{kg} \mathrm{CO}_{2} / \mathrm{m}^{2}\right)$

$E F=$ Embodied $\mathrm{GHG}$ for building $=6.7 \mathrm{~kg} \mathrm{CO} 2 / \mathrm{m}^{2}$

$A=$ Building's area

The results of the analysis of carbon footprints by seven Tourism Villages were then used as a reference to build "The Low-Carbon Sustainable Tourism Village Model".

\section{Results}

\subsection{Resources and Visitor Arrival in Tourism Village}

Based on this study, six of the Tourism Villages were located at the foot of mountains, with only Kandri situated on the highland near Semarang City. This indicated that Lerep and Candirejo were located on the foothills of Mt. Ungaran and Sumbing, which is not far from the Borobudur Temple. In addition, Karangrejo (the same district as Candirejo) was located on the foothill of Mt. Menoreh, with the Dieng Kulon site situated on the Dieng Plateau between Mt. Sindoro and Sumbing. Meanwhile, Pentingsari was found on the foothill of Mt. Merapi. All these villages had beautiful green landscapes and cool weather, as well as peaceful recreational areas. These seven Tourism Villages also have several venues and products as tourist attractions, as presented by Table 3 .

Table 3. Venues and attractions of the seven Tourism Villages in Indonesia considered in this study.

\begin{tabular}{|c|c|c|c|}
\hline No. & Tourism Village & Venues & Tourism Products \\
\hline 1. & Kandri & $\begin{array}{l}\text { (1) Natural venues: Kandri Lake, Gede Lake, Jamu } \\
\text { Lake, Kreo Cave, Monkeys population at Kreo } \\
\text { Cave; Jatibarang Dam; (2) Culinary venues: Centre } \\
\text { of Chips and Cassava Production; Beverages } \\
\text { product; Cassava product home industries (Omah } \\
\text { Pohung); (3) Omah Alas Art and Culture Studio; } \\
\text { (4) Tourist Information Centre; (5) Home Stays }\end{array}$ & $\begin{array}{c}\text { Packages: "Paket Nyawah (Planted Paddy } \\
\text { Package)", "Paket Petik Jambu" (Picking } \\
\text { Guava Package) }\end{array}$ \\
\hline 2. & Lerep & $\begin{array}{l}\text { (1) Natural venues: Curug Indrakila Waterfall; } \\
\text { Embung Sebligo Waterboom; Watu Gunung } \\
\text { Natural Swimming Pool; (2) Home Stays }\end{array}$ & $\begin{array}{l}\text { Packages: Education-Tourism Packages (A-F } \\
\text { Packages), Eco-Edu Tour Package }\end{array}$ \\
\hline 3. & Candirejo & $\begin{array}{l}\text { (1) Natural sites: Watu Kendil, Tempuran, Tuk } \\
\text { Banyu Asin (Ancient Lake); (2) Shops: Food } \\
\text { product, stone handycraft, and miscellanous } \\
\text { handycraft shops; (3) Home Stays }\end{array}$ & $\begin{array}{l}\text { Packages: One Day Field Trip, Half-Day Field } \\
\text { Trip, Live In, Rafting, Dokar (horse cart) } \\
\text { Village Tour, Cycling Tour, Live-In, } \\
\text { Walking-Around Village, Village Experience, } \\
\text { Cooking Lesson, Traditional Dance }\end{array}$ \\
\hline
\end{tabular}


Table 3. Cont.

\begin{tabular}{|c|c|c|c|}
\hline No. & Tourism Village & Venues & Tourism Products \\
\hline 4. & Karangrejo & $\begin{array}{l}\text { (1) Natural venues: Punthu Setumbuk (Dove Hill), } \\
\text { Barede Hill, Chicken Churh, Karangrejo Fruit Park; } \\
\text { (2) Shops: Batik Shop, Culinary Shops; (3) Home } \\
\text { Stays; (4) Events: Sedekah Bumi (Traditional } \\
\text { Thanksgiving Ceremony), Desa Budaya } \\
\text { (Cultural Village) }\end{array}$ & $\begin{array}{l}\text { Packages: Traditional Farming Education, Jeep } \\
\text { Sumringah Tour, VW (Volks Wagen) Sumilir } \\
\text { Packages, Onthel Manunggal (Biking Tour) }\end{array}$ \\
\hline 5. & Dieng Kulon & $\begin{array}{c}\text { (1) Natural venues: Sikidang Crater, Arjuna } \\
\text { Temple, and Kaliasa Dieng Museum; (2) Culinary } \\
\text { shops; (3) Home Stays; (4) Events: Dieng Kulon } \\
\text { Festival, Jazz Above the Sky }\end{array}$ & Non-Package \\
\hline 6. & Samiran & $\begin{array}{l}\text { (1) Natural venues: Gua Raja (King Cave), } \\
\text { Petilasan Kebo Kanigara (Kebo Kanigara) Heritage } \\
\text { Site, Mt. Merapi, Mt. Merbabu, Argadewi } \\
\text { Agro-Tourism; (2) Shops: Diary products shops, } \\
\text { Vegetables Shops; (3) Home Stays }\end{array}$ & $\begin{array}{l}\text { Packages: custom-made packages, One-Day } \\
\text { Package, Two-Days Package, Wisata Petik } \\
\text { Sayur (Picking Vegetables Package), learning } \\
\text { gamelan (traditional Javanese music } \\
\text { instruments) packages, milking cows learning } \\
\text { package, Reog Dance learning package. }\end{array}$ \\
\hline 7. & Pentingsari & $\begin{array}{l}\text { (1) Natural venue: Outbond Area; (2) Restaurants: } \\
\text { Warunge Simbok (Mom's Cafetaria); (3) Shops: } \\
\text { Batik Shop, Culinary Shops; (4) Home Stays }\end{array}$ & $\begin{array}{c}\text { Packages: Family Package, Live-In; Jeep Lava } \\
\text { Tour Merapi }\end{array}$ \\
\hline
\end{tabular}

Among the seven Tourism Villages, Pentingsari and Lerep had the smallest $\left(103 \mathrm{~km}^{2}\right)$ and largest $\left(682 \mathrm{~km}^{2}\right)$ areas with the biggest population (9000 persons), respectively, as shown by Table 4 . The monthly visitor arrivals were observed before and during the COVID-19 pandemic (2019-2020 and 2020-2021), indicating a drastic decline in all Tourism Villages between 2020-2021 (Table 5). Moreover, four Tourism Villages (Lerep, Candirejo, Karangrejo, and Pentingsari) had zero visitors until December 2021, with Dieng Kulon still having a significant number of tourists during the pandemic $(45,000$ visitors $)$ to present.

Table 4. Area and population of the seven Tourism Villages in Indonesia considered in this study.

\begin{tabular}{ccccc}
\hline No. & Tourism Village & Area $\mathbf{( \mathbf { k m } ^ { \mathbf { 2 } } )}$ & $\begin{array}{c}\text { Population } \\
\text { (Person) }\end{array}$ & $\begin{array}{c}\text { Population Density } \\
\mathbf{( P e r s o n} / \mathbf{k m} \mathbf{2})\end{array}$ \\
\hline 1. & Kandri & 319.64 & 3797 & 11.88 \\
2. & Lerep & 682 & 9000 & 13.20 \\
3. & Candirejo & 300.63 & 4700 & 15.63 \\
4. & Karangrejo & 174 & 3016 & 17.33 \\
5. & Dieng Kulon & 210 & 5300 & 25.24 \\
6 & Samiran & 631.11 & 3715 & 5.89 \\
7 & Pentingsari & 103 & 390 & 3.79 \\
\hline
\end{tabular}

Table 5. Visitor arrivals in the seven Tourism Villages in Indonesia considered in this study before and during the pandemic.

\begin{tabular}{|c|c|c|c|c|c|c|}
\hline \multirow{2}{*}{ No. } & \multirow{2}{*}{$\begin{array}{l}\text { Tourism } \\
\text { Village }\end{array}$} & \multirow{2}{*}{$\begin{array}{l}\text { Population } \\
\text { (Person) }\end{array}$} & \multicolumn{2}{|c|}{$\begin{array}{l}\text { Visitor's Arrival } \\
\text { per Month }\end{array}$} & \multicolumn{2}{|c|}{$\begin{array}{c}\text { The Ratio of Visitor to } \\
\text { Population }\end{array}$} \\
\hline & & & $\begin{array}{c}\text { Before Pandemic } \\
\text { (Person) }\end{array}$ & $\begin{array}{l}\text { During Pandemic } \\
\text { (Person) }\end{array}$ & $\begin{array}{c}\text { Before } \\
\text { Pandemic (\%) }\end{array}$ & $\begin{array}{c}\text { During } \\
\text { Pandemic (\%) }\end{array}$ \\
\hline 1. & Kandri & 3797 & 1000 & 100 & 26.34 & 2.63 \\
\hline 2. & Lerep & 9000 & 4942 & 0 & 54.91 & 0 \\
\hline 3. & Candirejo & 4700 & 750 & 0 & 15.96 & 0 \\
\hline 4. & Karangrejo & 3016 & 4000 & 0 & 132.63 & 0 \\
\hline 5. & Dieng Kulon & 5300 & 61,500 & 45,000 & 1160.38 & 849.06 \\
\hline 6. & Samiran & 3715 & 1030 & 285 & 27.73 & 7.67 \\
\hline 7. & Pentingsari & 390 & 2083 & 0 & 534.10 & 0 \\
\hline
\end{tabular}




\subsection{Solid Waste Carbon Footprint}

According to the field survey, several types of solid waste were found to exist in all Tourism Villages, i.e., food, paper, plastic, and organic pollutants. Since the exact volume of these wastes were unable to be obtained through field survey, significant assumptions were stated based on the number of visitors [28], as shown in Table 5. This indicated that the solid waste volume of seven Tourism Villages was individually calculated daily, with four pollutant categories (food, paper, plastic, and organic) being observed. In addition, the solid waste volume produced by these villages is shown in Figure 3.

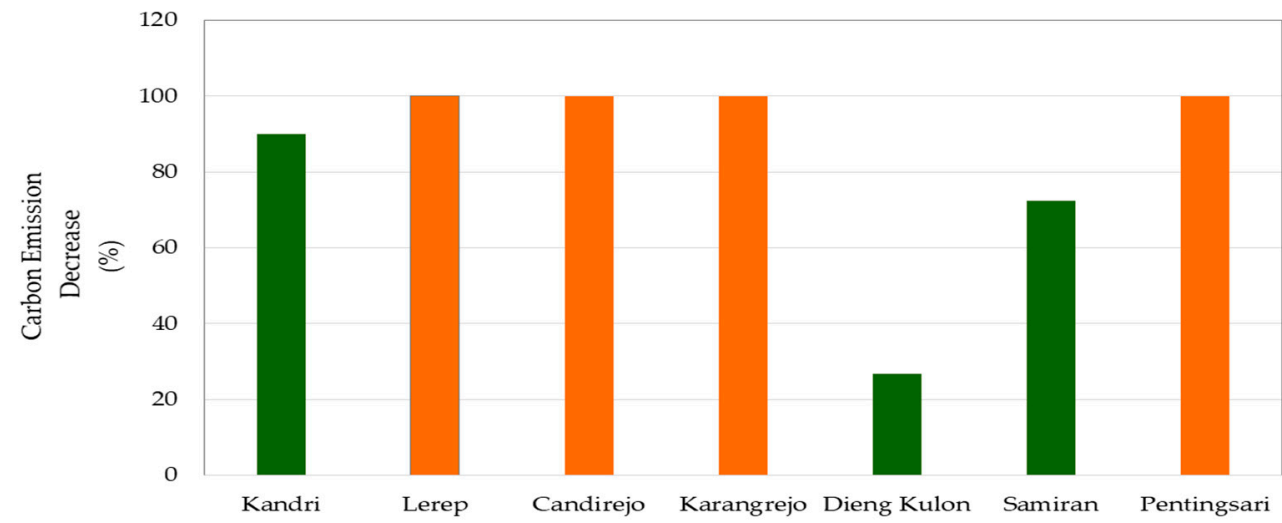

Figure 3. Solid waste $\mathrm{CO}_{2}$ emission decrease of the seven Tourism Villages in Indonesia considered in this study.

Based on Tables 6 and 7 the solid wastes produced by the tourists before and during the COVID-19 pandemic were described, respectively. According to Table 6, Dieng Kulon produced the biggest solid waste volumes of 913,644 and $668,520 \mathrm{~kg} /$ month before and during the pandemic, respectively. The results also showed that the largest organic solid waste volume was found in Dieng Kulon at 609,772.50 and 446,175 kg/month, before and during the COVID-19 pandemic, respectively. Furthermore, the Candirejo and Kandri had the smallest solid waste volumes of 11,142 and $1485.60 \mathrm{~kg} / \mathrm{month}$ before and during this pandemic, respectively. Based on seven Tourism Villages before the pandemic, Candirejo was found to have the smallest volume of food waste at $522 \mathrm{~kg} /$ month. Meanwhile, zero visitors were recorded for Candirejo, Lerep, Karangrejo, and Pentingsari during the pandemic. The results also showed that Lerep and Pentingsari had large organic solid waste volumes of $48,999.93$ and $20,652.95 \mathrm{~kg} / \mathrm{month}$ before the pandemic, from a total of $73,418.35$ and $30,945.05 \mathrm{~kg} /$ month, respectively. Paper and plastic wastes were found in large volumes at Lerep (11,164 and $9815 \mathrm{~kg} / \mathrm{month}$ ) and Karangrejo (9036 and $7944 \mathrm{~kg} /$ month) before the COVID-19 pandemic. This indicates that the organic solid waste volume was quite high in most Tourism Villages before the COVID-19 pandemic.

Table 6. The solid waste volume produced by the visitors of the seven Tourism Villages in Indonesia considered in this study before the COVID-19 pandemic.

\begin{tabular}{|c|c|c|c|c|c|c|c|}
\hline \multirow[b]{2}{*}{ No. } & \multirow{2}{*}{$\begin{array}{l}\text { Tourism } \\
\text { Village }\end{array}$} & \multirow{2}{*}{$\begin{array}{l}\text { Visitor before } \\
\text { Pandemic } \\
\text { (Person/Month) }\end{array}$} & \multicolumn{4}{|c|}{ Solid Waste Volume per Category before Pandemic } & \multirow{2}{*}{$\begin{array}{l}\text { Total Solid Waste } \\
\text { Volume before } \\
\text { Pandemic }\end{array}$} \\
\hline & & & $\begin{array}{c}\text { Food } \\
\text { (kg/Month) }\end{array}$ & $\begin{array}{c}\text { Paper } \\
\text { (kg/Month) }\end{array}$ & $\begin{array}{c}\text { Plastic } \\
\text { (kg/Month) }\end{array}$ & $\begin{array}{c}\text { Organic } \\
\text { (kg/Month) }\end{array}$ & \\
\hline 1. & Kandri & 1000 & 696.00 & 2259.00 & 1986.00 & 9915.00 & $14,856.00$ \\
\hline 2. & Lerep & 4942 & 3439.63 & $11,163.98$ & 9814.81 & $48,999.93$ & $73,418.35$ \\
\hline 3. & Candirejo & 750 & 522.00 & 1694.25 & 1489.50 & 7436.25 & $11,142.00$ \\
\hline 4. & Karangrejo & 4000 & 2784.00 & 9036.00 & 7944.00 & $39,660.00$ & $59,424.00$ \\
\hline 5. & Dieng Kulon & 61,500 & $42,804.00$ & $138,928.50$ & $122,139.00$ & $609,772.50$ & $913,644.00$ \\
\hline 6. & Samiran & 1030 & 716.88 & 2326.77 & 2045.58 & $10,212.45$ & $15,301.68$ \\
\hline 7. & Pentingsari & 2083 & 1449.77 & 4705.50 & 4136.84 & $20,652.95$ & $30,945.05$ \\
\hline
\end{tabular}


Table 7. The solid waste volume produced by the visitors of the seven Tourism Villages in Indonesia considered in this study during the COVID-19 pandemic.

\begin{tabular}{|c|c|c|c|c|c|c|c|}
\hline \multirow[b]{2}{*}{ No. } & \multirow{2}{*}{$\begin{array}{l}\text { Tourism } \\
\text { Village }\end{array}$} & \multirow{2}{*}{$\begin{array}{l}\text { Visitor during } \\
\text { Pandemic } \\
\text { (Person/Month) }\end{array}$} & \multicolumn{4}{|c|}{ Waste Volume per Category during Pandemic } & \multirow{2}{*}{$\begin{array}{c}\text { Total Waste } \\
\text { Volume during } \\
\text { Pandemic }\end{array}$} \\
\hline & & & $\begin{array}{c}\text { Food } \\
\text { (kg/Month) }\end{array}$ & $\begin{array}{c}\text { Paper } \\
\text { (kg/Month) }\end{array}$ & $\begin{array}{c}\text { Plastic } \\
\text { (kg/Month) }\end{array}$ & $\begin{array}{c}\text { Organic } \\
\text { (kg/Month) }\end{array}$ & \\
\hline 1. & Kandri & 100 & 69.60 & 225.90 & 198.60 & 991.50 & 1485.60 \\
\hline 2. & Lerep & 0 & 0 & 0 & 0 & 0 & 0 \\
\hline 3. & Candirejo & 0 & 0 & 0 & 0 & 0 & 0 \\
\hline 4. & Karangrejo & 0 & 0 & 0 & 0 & 0 & 0 \\
\hline 5. & Dieng Kulon & 45,000 & $31,320.00$ & $101,655.00$ & $89,370.00$ & $446,175.00$ & $668,520.00$ \\
\hline 6. & Samiran & 285 & 198.36 & 643.82 & 566.01 & 2825.78 & 4233.96 \\
\hline 7. & Pentingsari & 0 & 0 & 0 & 0 & 0 & 0 \\
\hline
\end{tabular}

Based on Equation (1), the $\mathrm{CO}_{2}$ emission of solid waste for all Tourism Villages was calculated (Table 8), indicating that Dieng Kulon had the largest monthly solid waste $\mathrm{CO}_{2}$ emission before and after the COVID-19 pandemic $(437,766.10 \mathrm{~kg} \mathrm{CO} / \mathrm{kg}$ and $320,316.66 \mathrm{~kg} \mathrm{CO}_{2} / \mathrm{kg}$ ). In addition, Lerep, Karangrejo, and Pentingsari only had high solid waste $\mathrm{CO}_{2}$ emissions $(35,177 \mathrm{~kg} \mathrm{CO} / \mathrm{kg}, 28,472.59 \mathrm{~kg} \mathrm{CO} / \mathrm{kg}$, and $14,827.10 \mathrm{~kg} \mathrm{CO} 2 / \mathrm{kg})$ before the pandemic. This was due to the zero values of solid waste $\mathrm{CO}_{2}$ emission during the COVID-19 pandemic. Meanwhile, only Kandri had the smallest solid waste $\mathrm{CO}_{2}$ emission before and during the COVID-19 pandemic $\left(7118.15 \mathrm{~kg} \mathrm{CO}_{2} / \mathrm{kg}\right.$ and $711.81 \mathrm{~kg} \mathrm{CO}_{2} / \mathrm{kg}$ ).

Table 8. $\mathrm{CO}_{2}$ solid waste emission of the seven Tourism Villages in Indonesia considered in this study before and during COVID-19 pandemic.

\begin{tabular}{|c|c|c|c|c|c|}
\hline \multirow{3}{*}{ No. } & \multirow{3}{*}{$\begin{array}{l}\text { Tourism } \\
\text { Village }\end{array}$} & \multirow{3}{*}{$\begin{array}{c}\text { Emission } \\
\text { Factor-Inorganic } \\
\text { Waste }\end{array}$} & \multirow{3}{*}{$\begin{array}{c}\text { Emission } \\
\text { Factor-Organic } \\
\text { Waste }\end{array}$} & \multicolumn{2}{|c|}{$\begin{array}{c}\text { Solid Waste Carbon Emission } \\
\text { Produced by Visitor }\end{array}$} \\
\hline & & & & $\begin{array}{c}\text { Before } \\
\text { Pandemic }\end{array}$ & $\begin{array}{c}\text { During } \\
\text { Pandemic }\end{array}$ \\
\hline & & & & $(\mathrm{kg} \mathrm{CO} / \mathrm{kg})$ & $\left(\mathrm{kg} \mathrm{CO}_{2} / \mathrm{kg}\right)$ \\
\hline 1. & Kandri & 0.668 & 0.450 & 7118.15 & 711.81 \\
\hline 2. & Lerep & 0.668 & 0.450 & $35,177.89$ & 0.00 \\
\hline 3. & Candirejo & 0.668 & 0.450 & 5338.61 & 0.00 \\
\hline 4. & Karangrejo & 0.668 & 0.450 & $28,472.59$ & 0.00 \\
\hline 5. & Dieng Kulon & 0.668 & 0.450 & $437,766.10$ & $320,316.66$ \\
\hline 6. & Samiran & 0.668 & 0.450 & 7331.69 & 2028.67 \\
\hline 7. & Pentingsari & 0.668 & 0.450 & $14,827.10$ & 0.00 \\
\hline
\end{tabular}

\subsection{Building's Carbon Footprint}

According to the field survey, the building types found in the seven Tourism Villages were the office, hall, homestay, public toilet, mosque, and shop (Table 9). The results showed that the homestays were the most numerous building types found in all the villages, with most existing in Dieng Kulon ( 265 buildings), accompanied by Kandri and Candirejo (90 and 80 buildings). Another building type also existing in large numbers was the shop, with Table 9 showing that Dieng Kulon, Lerep, and Samiran had 60, 20, and 15 shops, respectively.

Based on this study, the number and volume of buildings existing in the seven Tourism Villages are shown in Table 10. This indicates that Pentingsari and Lerep, Karangejo and Kandri, as well as Dieng Kulon and Kandri, had the lowest and highest building areas (103 and $682 \mathrm{ha}$ ), numbers (91 and 340 buildings), and average volumes (210 and $400 \mathrm{~m}^{3}$ ), respectively. According to Table 10, Pentingsari also had the highest building area ratio of $223.30 \%$, accompanied by Karangrejo and Kandri at $155.17 \%$ and $125.14 \%$, respectively. 
Table 9. The types of buildings in the seven Tourism Villages in Indonesia considered in this study.

\begin{tabular}{|c|c|c|c|c|c|c|c|c|}
\hline \multirow{2}{*}{ No. } & \multirow{2}{*}{$\begin{array}{l}\text { Tourism } \\
\text { Village }\end{array}$} & \multicolumn{6}{|c|}{ Type of Building } & \multirow{2}{*}{$\begin{array}{c}\text { Total Number } \\
\text { of Buildings }\end{array}$} \\
\hline & & Office & Hall & Home Stay & Public Toilet & Mosque & Shop & \\
\hline 1. & Kandri & 1 & 4 & 90 & 3 & 4 & 3 & 105 \\
\hline 2. & Lerep & 1 & 3 & 50 & 4 & 13 & 20 & 91 \\
\hline 3. & Candirejo & 1 & 3 & 80 & 8 & 15 & 5 & 112 \\
\hline 4. & Karangrejo & 10 & 3 & 50 & 6 & 6 & 7 & 82 \\
\hline 5. & Dieng Kulon & 1 & 3 & 265 & 0 & 11 & 60 & 340 \\
\hline 6. & Samiran & 2 & 2 & 45 & 6 & 3 & 15 & 73 \\
\hline 7. & Pentingsari & 1 & 6 & 50 & 40 & 2 & 6 & 105 \\
\hline
\end{tabular}

Table 10. The ratio of building number to the area of the seven Tourism Villages in Indonesia considered in this study.

\begin{tabular}{|c|c|c|c|c|c|c|}
\hline No. & $\begin{array}{l}\text { Tourism } \\
\text { Village }\end{array}$ & $\begin{array}{l}\text { Area } \\
\text { (ha) }\end{array}$ & $\begin{array}{l}\text { Number of } \\
\text { Buildings } \\
\text { (pcs) }\end{array}$ & $\begin{array}{c}\text { Average } \\
\text { Building's Area } \\
\left(\mathrm{m}^{2}\right)\end{array}$ & $\begin{array}{c}\text { Total Building's } \\
\text { Area } \\
\left(\mathrm{m}^{3}\right)\end{array}$ & $\begin{array}{l}\text { Ratio of Building's } \\
\text { Number to Area } \\
\text { (Building/m²) }\end{array}$ \\
\hline 1. & Kandri & 320 & 105 & 133.33 & $14,000.00$ & 0.33 \\
\hline 2. & Lerep & 682 & 91 & 100.00 & 9100.00 & 0.13 \\
\hline 3. & Candirejo & 301 & 112 & 83.33 & 9333.33 & 0.37 \\
\hline 4. & Karangrejo & 174 & 82 & 90.00 & 7380.00 & 0.47 \\
\hline 5. & Dieng Kulon & 210 & 340 & 70.00 & $23,800.00$ & 1.62 \\
\hline 6. & Samiran & 631 & 73 & 76.67 & 5596.67 & 0.12 \\
\hline 7. & Pentingsari & 103 & 105 & 76.67 & 8050.00 & 1.02 \\
\hline
\end{tabular}

Using Equation (2), all the building types in the seven Tourism Villages were calculated for building's $\mathrm{CO}_{2}$ emission. According to Table 11, the homestays had the highest $\mathrm{CO}_{2}$ emission of $80-90 \%$ in all locations. Also, the highest and lowest total building's $\mathrm{CO}_{2}$ emissions were observed at Dieng Kulon $\left(159,460 \mathrm{~kg} \mathrm{CO}_{2} / \mathrm{m}^{2}\right)$ and Samiran $\left(37,499.30 \mathrm{~kg} \mathrm{CO} 2 / \mathrm{m}^{2}\right)$, respectively. Kandri also had approximately $86 \%$ of the highest home stay's $\mathrm{CO}_{2}$ emission at $80,398 \mathrm{~kg} \mathrm{CO} / \mathrm{m}^{2}$. In addition, Lerep, Candirejo, and Pentingsari had about $25-30 \%$ home stay's $\mathrm{CO}_{2}$ emission compared to total building's $\mathrm{CO}_{2}$ emissions respectively.

Table 11. The building's $\mathrm{CO}_{2}$ emission of the seven Tourism Villages in Indonesia considered in this study.

\begin{tabular}{|c|c|c|c|c|c|c|c|c|}
\hline \multirow{2}{*}{ No. } & \multirow{2}{*}{$\begin{array}{l}\text { Tourism } \\
\text { Village }\end{array}$} & \multicolumn{6}{|c|}{ Building's $\mathrm{CO}_{2}$ Emission $\left(\mathrm{kg} \mathrm{CO} \mathrm{CO}_{2} / \mathrm{m}^{2}\right)$} & \multirow{2}{*}{$\begin{array}{l}\text { Total Building's } \mathrm{CO}_{2} \\
\text { Emission }\left(\mathrm{kg} \mathrm{CO} \mathrm{CO}_{2} / \mathrm{m}^{2}\right)\end{array}$} \\
\hline & & Office & Hall & Home Stay & Public Toilet & Mosque & Shops & \\
\hline 1. & Kandri & 893 & 3573 & 80,398 & 2680 & 3573 & 2680 & $93,797.66$ \\
\hline 2. & Lerep & 670 & 2010 & 33,500 & 2680 & 8710 & 13,400 & $60,970.00$ \\
\hline 3. & Candirejo & 558 & 1675 & 44,665 & 4466 & 8375 & 2792 & $62,530.83$ \\
\hline 4. & Karangrejo & 6030 & 1809 & 30,150 & 3618 & 3618 & 4221 & $49,446.00$ \\
\hline 5. & Dieng Kulon & 469 & 1407 & 124,285 & 0 & 5159 & 28,140 & $159,460.00$ \\
\hline 6. & Samiran & 1027 & 1027 & 23,116 & 3082 & 1541 & 7705 & $37,499.30$ \\
\hline 7. & Pentingsari & 514 & 3082 & 25,684 & 20,548 & 1027 & 3082 & $53,937.35$ \\
\hline
\end{tabular}

\section{Discussion}

\subsection{Carbon Footprint Analysis}

Based on this study, the seven Tourism Villages had beautiful scenes that were very attractive to both domestic and foreign visitors, with all the locations having low population densities (Tables 2 and 3). However, the arrival of visitors before the pandemic was very high, with the minimum and maximum values observed at Candirejo and Dieng Kulon (750 and 61,500 visitors/month), respectively. The high values of Dieng Kulon were due 
to the famous scenes of the Dieng Plateau and Arjuna Temple. Despite the decline during the COVID-19 pandemic, the solid waste and $\mathrm{CO}_{2}$ emissions produced in this area were still high (Figure 4). Based on Figure 3, the four villages (Lerep, Candirejo, Karangrejo, and Pentingsari) with zero visitors during the pandemic were represented by orange bars. From these four villages, 3 locations (Lerep, Karangrejo, and Pentingsari) still had high $\mathrm{CO}_{2}$ emissions $(35,177.89 \mathrm{~kg} \mathrm{CO}, 28,472.59 \mathrm{~kg} \mathrm{CO}$, and $14,827.10 \mathrm{~kg} \mathrm{CO}$ ), as illustrated in Figure 4. However, there was no significant reduction guarantee towards future visits. In this study, organic waste had the highest volume before and during the COVID-19 pandemic, indicating a large $\mathrm{CO}_{2}$ emission contribution (Figure 3). By implementing waste recycling as a proper management technique, the concerns of organic pollutants in these Tourism Villages should not be a problem.

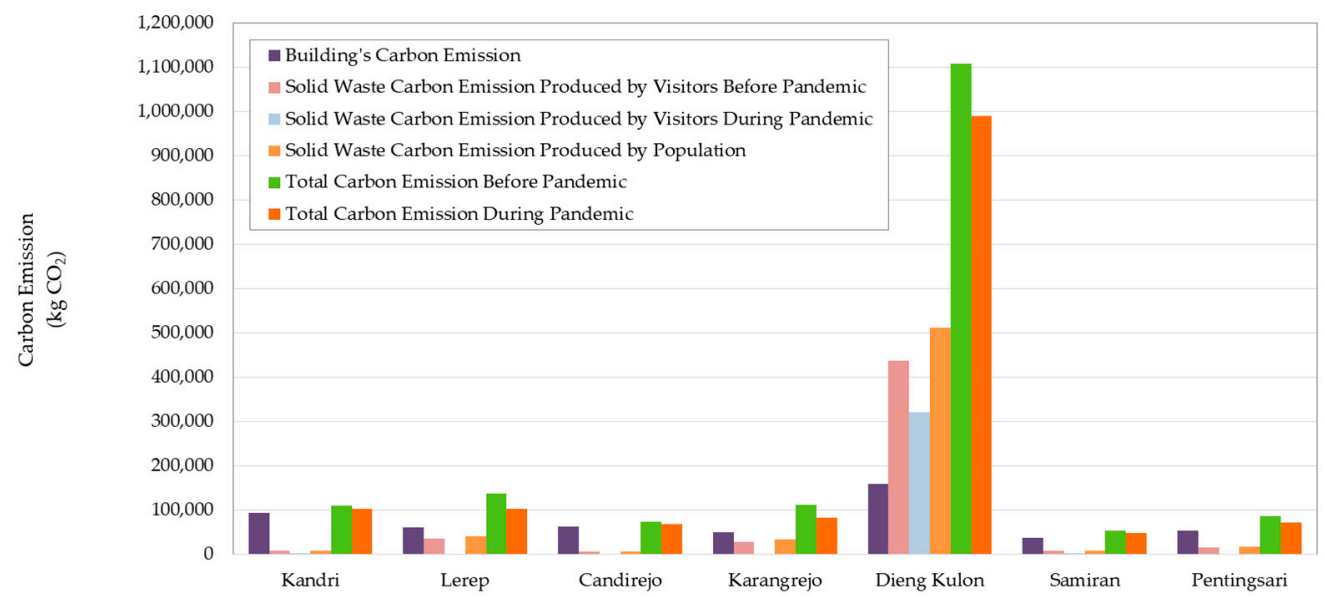

Figure 4. $\mathrm{CO}_{2}$ emissions from several sources produced by the seven Tourism Villages in Indonesia considered in this study.

It is obvious that a large number of visitors and population will produce a large volume of waste, as discussed in the previous sub-section. However, a comparison among the tourism areas should provide a better understanding of the waste produced by the activities of a certain population. This led to the comparisons of the solid waste produced by the seven Tourism Villages with that produced by the Nusa Penida Islands. This tourism location had three subareas, namely Nusa Peninda, Lembongan, and Ceningan Islands, respectively. The waste volume data of the Nusa Penida Islands was in line with a previous study [20], and also current study which is explained by Table 9, where the Emission Factor (0.559) used for calculation was the average value of rural household inorganic (0.668) and organic (0.45) pollutants. Table 12 indicates that all seven Tourism Villages in this study produced a larger waste volume compared to those in Nusa Penida Islands. Therefore, the $\mathrm{CO}_{2}$ emission produced by the solid waste in these villages was between $200-22,000 \%$ larger than the waste $\mathrm{CO}_{2}$ emission in the Nusa Penida Islands. Despite Nusa Penida Island having the highest population and density (190.04 person $/ \mathrm{km}^{2}$ ) among all the locations in Table 12, it still only produced a carbon emission of $2299 \mathrm{~kg} \mathrm{CO}$. Besides that, Lerep had the largest population (9000 persons) among the seven Tourism Villages, although it was not the most crowded location, as the density was only observed at 13.20 person $/ \mathrm{km}^{2}$. Meanwhile, Dieng Kulon was the most crowded at 25.24 person $/ \mathrm{km}^{2}$, thereby becoming the highest contributor of carbon emission at $510,727 \mathrm{~kg} \mathrm{CO} / \mathrm{kg}$.

Based on this study, it is interesting to analyze the carbon emission produced by the population of both Dieng Kulon and Nusa Penida Island (Table 12). Although the population density of Dieng Kulon was only $13.28 \%$ that of Nusa Penida Island, the waste $\mathrm{CO}_{2}$ emission was still 22,215.19\%. This shows that when the wastes produced by the visitors and population of Dieng Kulon were added together before the pandemic (Tables 5 and 8), the waste $\mathrm{CO}_{2}$ emission was $948,493.10 \mathrm{~kg} \mathrm{CO} / \mathrm{kg}$. According to [20], the visitors of Nusa Penida Islands (all 3 islands included) were 391,071 daily or 11,732,130 monthly, 
subsequently producing waste of $5208.3 \mathrm{~kg} /$ month. After calculations, the total waste $\mathrm{CO}_{2}$ emission was found at $34,157,389,047.56 \mathrm{~kg} \mathrm{CO}_{2} / \mathrm{kg}$ or $34,157,389.05 \mathrm{t} \mathrm{CO}_{2} / \mathrm{kg}$. This indicated that a large number of visitors generated high carbon waste emissions, which was in line with the data of Dieng Kulon and Nusa Penida Island. However, further analysis showed that each visitor in Nusa Penida Islands and Dieng Kulon only produced wastes of $0.00044 / 172.39 \mathrm{~kg} /$ day or $0.01332 / 5.75 \mathrm{~kg} /$ month, respectively. This indicated that each person in Dieng Kulon contributed higher waste $\mathrm{CO}_{2}$ emission $(96.36 \mathrm{~kg} \mathrm{CO} / \mathrm{kg}$ per day or $3.21 \mathrm{~kg} \mathrm{CO} 2 / \mathrm{kg}$ per month) than those in the Nusa Penida Islands $\left(0.00025 \mathrm{~kg} \mathrm{CO}_{2} / \mathrm{kg}\right.$ per day or $0.00745 \mathrm{~kg} \mathrm{CO}_{2} / \mathrm{kg}$ per month).

Table 12. The waste volume and $\mathrm{CO}_{2}$ emission produced by the population of the seven Tourism Villages in Indonesia considered in this study and the Nusa Penida Islands.

\begin{tabular}{|c|c|c|c|c|c|c|c|}
\hline Location & $\begin{array}{c}\text { Area } \\
\left(\mathrm{km}^{2}\right)\end{array}$ & $\begin{array}{l}\text { Population } \\
\text { (Person) }\end{array}$ & $\begin{array}{c}\text { Population } \\
\text { Density } \\
(\text { Person/km²) }\end{array}$ & $\begin{array}{l}\text { Solid Waste } \\
\text { Composition }\end{array}$ & $\begin{array}{c}\text { Total } \\
\text { Volume of } \\
\text { Solid Waste }\end{array}$ & $\begin{array}{l}\text { Average } \\
\text { Emission } \\
\text { Factor }\end{array}$ & $\begin{array}{c}\mathrm{CO}_{2} \\
\text { Emission } \\
(\mathrm{kg} \mathrm{CO} / \mathrm{kg})\end{array}$ \\
\hline Kandri & 319.64 & 3797 & 11.88 & \multirow{7}{*}{$\begin{array}{l}\text { Food, paper, plastic, } \\
\text { organic waste }\end{array}$} & 14,856 & 0.559 & 8304.50 \\
\hline Lerep & 682 & 9000 & 13.20 & & 73,418 & 0.559 & $41,040.66$ \\
\hline Candirejo & 300.63 & 4700 & 15.63 & & 11,142 & 0.559 & 6228.38 \\
\hline Karangrejo & 174 & 3016 & 17.33 & & 59,424 & 0.559 & $33,218.02$ \\
\hline Dieng Kulon & 210 & 5300 & 25.24 & & 913,644 & 0.559 & $510,727.00$ \\
\hline Samiran & 631.11 & 3715 & 5.89 & & 15,302 & 0.559 & 8553.82 \\
\hline Pentingsari & 103 & 390 & 3.79 & & 30,945 & 0.559 & $17,298.26$ \\
\hline $\begin{array}{c}\text { Nusa } \\
\text { Penida * }\end{array}$ & 202.17 & 38,421 & 190.04 & \multirow{3}{*}{$\begin{array}{l}\text { Food, wood and } \\
\text { garden waste, paper, } \\
\text { textile, rubber and } \\
\text { leather, plastic, glass, } \\
\text { metal, hazardous } \\
\text { waste, etc. }\end{array}$} & 4112.70 & 0.559 & 2299.00 \\
\hline $\begin{array}{c}\text { Nusa } \\
\text { Lembongan * }\end{array}$ & 800 & 5163 & 6.45 & & 764.40 & 0.559 & 427.30 \\
\hline $\begin{array}{c}\text { Nusa } \\
\text { Ceningan * }\end{array}$ & 300.9 & 1992 & 6.62 & & 331.20 & 0.559 & 185.14 \\
\hline
\end{tabular}

* Data of population and daily waste volume referred to [20].

Based on Tables 10 and 11, Dieng Kulon and Samiran had the highest and lowest ratios of area numbers (1.62 and 0.12) and $\mathrm{CO}_{2}$ emissions $\left(159,460\right.$ and $\left.377,499.3 \mathrm{~kg} \mathrm{CO} 2 / \mathrm{m}^{2}\right)$, respectively. This indicates that the large values of building's $\mathrm{CO}_{2}$ emission were due to the high number of existing buildings in the area. According to this study, Dieng Kulon had the largest number of buildings (340 buildings), with most found to be homestays (265 homestays). Therefore, the $\mathrm{CO}_{2}$ emission produced by the seven Tourism Villages was a 'red flag' of environmental quality degradation, which should immediately be mitigated. In wider aspects, Dieng Kulon was found as the 'top rank' contributor of carbon emissions, as shown in Figure 4. This was because the large population and a great number of visitors had made this village a 'giant' of $\mathrm{CO}_{2}$ emission, compared to Nusa Penida Islands (Table 12). In addition, Figure 4 showed that Kandri and Lerep had slightly larger carbon emissions compared to Candirejo, Karangrejo, Samiran, and Pentingsari. This indicates that most of the Tourism Villages (Dieng Kulon Village excluded) had larger carbon waste from buildings than the solid pollutant emission. Therefore, the high solid-waste $\mathrm{CO}_{2}$ emission in Dieng Kulon was contributed by visitors and the population.

Based on Table 13, Dieng Kulon had the highest $\mathrm{CO}_{2}$ emissions from all sources (solid waste produced by visitors, population, and buildings). The results also showed that Candirejo had the lowest emission produced by the visitors and population, before the COVID-19 pandemic. However, Kandri and Samiran had the lowest $\mathrm{CO}_{2}$ emissions produced by visitors and buildings, respectively. 
Table 13. The maximum and minimum $\mathrm{CO}_{2}$ emissions from all sources in the current study.

\begin{tabular}{|c|c|c|c|}
\hline No. & Types of Carbon Emission & $\begin{array}{c}\text { Maximum } \\
\text { (Tourism Village, } \\
\text { Amount) }\end{array}$ & $\begin{array}{c}\text { Minimum } \\
\text { (Tourism Village, } \\
\text { Amount) }\end{array}$ \\
\hline 1. & $\begin{array}{l}\text { Solid waste } \mathrm{CO}_{2} \text { emission produced } \\
\text { by visitors before the pandemic }\end{array}$ & $\begin{array}{c}\text { Dieng Kulon } \\
437,766.10 \\
\mathrm{~kg} \mathrm{CO}_{2} / \mathrm{kg}\end{array}$ & $\begin{array}{c}\text { Candirejo } \\
5338.61 \\
\mathrm{~kg} \mathrm{CO}_{2} / \mathrm{kg}\end{array}$ \\
\hline 2. & $\begin{array}{l}\text { Solid waste } \mathrm{CO}_{2} \text { emission produced } \\
\text { by visitors during the pandemic }\end{array}$ & $\begin{array}{c}\text { Dieng Kulon } \\
320,316.66 \\
\mathrm{~kg} \mathrm{CO}_{2} / \mathrm{kg}\end{array}$ & $\begin{array}{c}\text { Kandri } \\
711.81 \\
\mathrm{~kg} \mathrm{CO}_{2} / \mathrm{kg}\end{array}$ \\
\hline 3. & $\begin{array}{l}\text { Solid waste } \mathrm{CO}_{2} \text { emission produced } \\
\text { by the population }\end{array}$ & $\begin{array}{c}\text { Dieng Kulon } \\
510,727.00 \\
\mathrm{~kg} \mathrm{CO}_{2} / \mathrm{kg}\end{array}$ & $\begin{array}{c}\text { Candirejo } \\
6228.38 \\
\mathrm{~kg} \mathrm{CO}_{2} / \mathrm{kg}\end{array}$ \\
\hline 4. & Building's $\mathrm{CO}_{2}$ emission & $\begin{array}{c}\text { Dieng Kulon } \\
159,460.00 \\
\mathrm{~kg} \mathrm{CO} 2 / \mathrm{m}^{2}\end{array}$ & $\begin{array}{c}\text { Samiran } \\
37,499.30 \\
\mathrm{~kg} \mathrm{CO}_{2} / \mathrm{m}^{2}\end{array}$ \\
\hline
\end{tabular}

This indicates that the high number of $\mathrm{CO}_{2}$ emissions was due to the large volume of solid waste produced by the visitors and the population. In addition, the high pollutant volume implied the bad habits of people (residents of the Tourism Villages and visitors) in producing solid wastes, and also the inappropriate trash management (3R-Reduce, Reuse, and Recycle).

\subsection{Comprehensive Model}

A low-carbon approach should be implemented in these seven Tourism Villages, including decreased energy consumption, pollution, and $\mathrm{CO}_{2}$ emissions [22]. This indicates that a change of paradigm is needed, due to individual awareness, attitudes, capacity to change, as well as social alterations such as the cultures and environments in Tourism Villages. Furthermore, a social education of low-carbon habits was necessary for achieving better environmental qualities (cleaner, healthier, and sustainable), indicating that the community should lead health management, create societal strength, and develop a sustainable Tourism Village [7]. The stakeholders (government, tourism village's community, population, tourists or visitors) of Tourism Village development should also be involved in implementing low-carbon sustainability [13].

Based on the problems of $\mathrm{CO}_{2}$ emissions produced by Tourism Villages, this study proposed a comprehensive model called the "Low-Carbon Sustainable Tourism Village Model" (Figure 5). The model essentials may be explained as follows. The model is described by a chart with several colors of rectangles to distinguish their meanings, which are also stated in the figure, and connected by arrows that described flow and causality. The Tourism Village is the center of this model, which is represented by a green rectangle because of its 'green characteristic'. However, the Tourism Village has contributed large $\mathrm{CO}_{2}$ emissions (which are represented by a red rectangle that marked it as very important aspect) from its elements (which are marked by orange rectangles) such as infrastructures, population, and visitors. The $\mathrm{CO}_{2}$ emissions produced by the Tourism Village's elements has contributed to climate change (that is marked by a blue rectangle). It is explained by the model that the buildings are infrastructure elements of the Tourism Village that produce a significant amount of $\mathrm{CO}_{2}$ emissions that may come from venues, homestays, heritage sites, shops, public infrastructures, etc. Due to the large contribution of carbon emissions from the Tourism Village, it is necessary to conduct carbon footprint reduction programs, i.e., waste management, evaluation of building operation and maintenance, energy efficiency, etc. These actions should be accompanied by the social education of low-carbon habits, such as promoting and building awareness, attitudes, and planning capacity, as well as implementing sustainable tourism programs. This educational method is expected to develop an essential low-carbon habit, which should involve internal stakeholders Tourism Village's community) and external stakeholders (government) due to 
policy, regulation, and law enforcement). Therefore, the low-carbon Tourism Village is a good way to achieve sustainability.

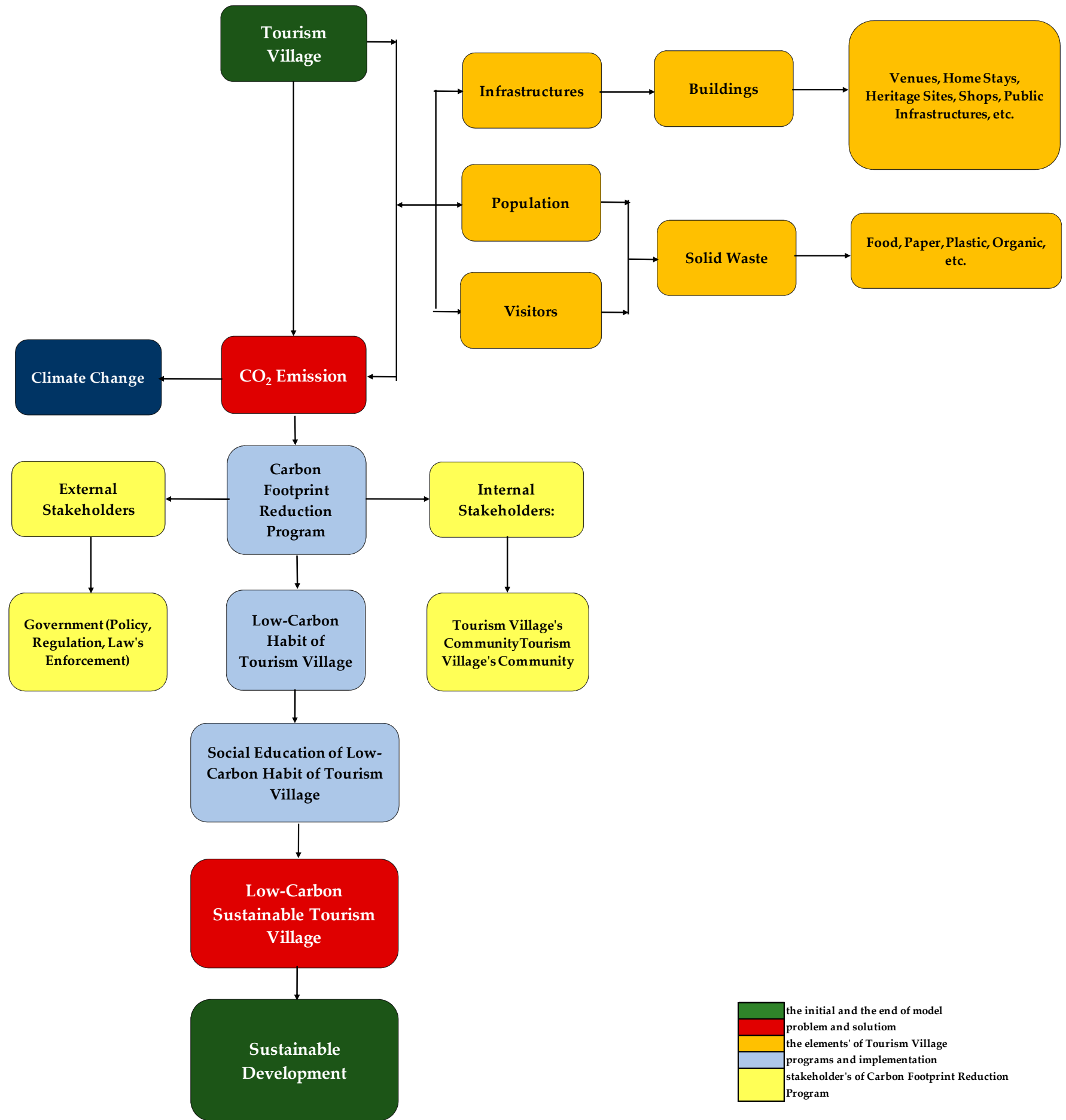

Figure 5. The Low-Carbon Sustainable Tourism Village Schematic Model.

\section{Conclusions}

This study focused on the high contribution of tourism activities to the carbon footprint. There is no doubt that Tourism Villages have contributed large $\mathrm{CO}_{2}$ emissions by the tourist attractions which were the main business of the seven Tourism Villages in Indonesia considered in this study, as well as in the heritage sites of Yogyakarta Special Region in Indonesia and also the Wulingyuan Scenic/Historic Interest Area (WSHIA) and 
Guizhou ethnic locations in China [11-13]. For the new concept of low-carbon tourism to be implemented to increase the wealth of the tourism industry's actors [7-10], several actions in low-carbon approaches are a necessity. Lessons learned about proper waste management from tourism areas of Madeira Island, Portugal [18] and Coachella Valley, California, USA [19] will be valuable to the Tourism Villages, which have large numbers of visitors and populations, as in Dieng Kulon Tourism Village. It is also important that buildings' life cycles related to energy consumption contain several stages, in addition to their operation and maintenance [25], which in Tourism Villages should be handled with high efficiency to reduce carbon emissions.

Hence, as a "carbon emission contributor" and "victim of the COVID-19 pandemic", the sustainability of Tourism Villages was found to be a key in the development of income, as well as obtaining a cleaner and healthier environment. This should subsequently become the vanguard to lead the economic recovery of rural communities after the pandemic, to reduce carbon emission and achieve sustainable development goals. In addition, the "The Low-Carbon Sustainable Tourism Village Model" was proposed by this study to answer the challenge of sustainability.

Author Contributions: Conceptualization, R.M.I.R.S., A.S. and A.I.; methodology, R.M.I.R.S. and A.I.; formal analysis, R.M.I.R.S.; investigation, A.I., B.Y.A.W., D.K.W., L.L.N.P. and A.H.A.; resources, A.I., B.Y.A.W., D.K.W., L.L.N.P. and A.H.A.; data curation, R.M.I.R.S. and A.I.; writing-original draft preparation, R.M.I.R.S.; writing-review and editing, R.M.I.R.S. and B.Y.A.W.; visualization, B.Y.A.W.; supervision, R.M.I.R.S.; project administration, D.K.W.; funding acquisition, R.M.I.R.S. and A.S. All authors have read and agreed to the published version of the manuscript.

Funding: This study was funded by the Ministry of Education, Culture, Research and Technology, Republic of Indonesia, through the Matching Fund Grant (2021) with Contract No. 3605/E3/PKS.08KL/ 2021 and No. 00342/H2Rek/09/2021.

Institutional Review Board Statement: Not applicable.

Informed Consent Statement: Not applicable.

Data Availability Statement: Not applicable.

Acknowledgments: The authors are grateful to all the study partners (AKSI, 7 Tourism Villages of Kandri, Lerep, Samiran, Karangrejo, Candirejo, Samiran, Dieng Kulon, and Pentingsari, BAPPEDA Central Java Province, Disporapar Central Java Province, in Indonesia) for a great collaboration towards the support of this study.

Conflicts of Interest: The authors declare no conflict of interest.

\section{References}

1. Masson-Delmotte, V.; Zhai, P.; Chen, Y.; Goldfarb, L.; Gomis, M.I.; Matthews, J.B.R.; Berger, S.; Huang, M.; Yelekçi, O.; Yu, R.; et al. Working Group I Contribution to the Sixth Assessment Report of the Intergovernmental Panel on Climate Change; Cambridge University Press: Cambridge, UK, 2021; In Press.

2. Nurhidayah, L. Sea-level rise (slr) and its implication on human security and human rights in indonesia: A legal analysis. Springer Clim. 2021, 2021, 33-52. [CrossRef]

3. Triyanti, A.; Marfai, M.A.; Mei, E.T.W.; Rafliana, I. Review of socio-economic development pathway scenarios for climate change adaptation in indonesia: Disaster risk reduction perspective. In Climate Change Research, Policy and Actions in Indonesia; Springer: Cham, Switzerland, 2021; ISBN 9783030555351.

4. Lenzen, M.; Sun, Y.Y.; Faturay, F.; Ting, Y.P.; Geschke, A.; Malik, A. The carbon footprint of global tourism. Nat. Clim. Chang. 2018, 8, 522-528. [CrossRef]

5. Sun, Y.; Malik, A. Tourism's Alarming—and Growing-Carbon Footprint. Available online: https://www.brinknews.com/ tourisms-alarming-and-growing-carbon-footprint/ (accessed on 10 December 2021).

6. Yang, W.; Zhao, R.; Chuai, X.; Xiao, L.; Cao, L.; Zhang, Z.; Yang, Q.; Yao, L. China's pathway to a low carbon economy. Carbon Balance Manag. 2019, 14, 14. [CrossRef] [PubMed]

7. Bhaktikul, K.; Aroonsrimorakot, S.; Laiphrakpam, M.; Paisantanakij, W. Toward a low-carbon tourism for sustainable development: A study based on a royal project for highland community development in Chiang Rai, Thailand. Environ. Dev. Sustain. 2021, 23, 10743-10762. [CrossRef] 
8. Töbelmann, D.; Wendler, T. The impact of environmental innovation on carbon dioxide emissions. J. Clean. Prod. 2020, $244,118787$. [CrossRef]

9. He, J.; Tu, X. On Sustainable Development of Low-carbon Tourism in Jiangxi Province. J. Phys. Conf. Ser. 2020, 1549, 1-6. [CrossRef]

10. Qiao, G.; Gao, J. Chinese tourists' perceptions of climate change and mitigation behavior: An application of norm activation theory. Sustainability 2017, 9, 1322. [CrossRef]

11. Saputra, E. An analysis of tourist carbon footprint in Indonesia-The case of D.I. Yogyakarta. Geogr. Malays. J. Soc. Sp. 2013, 9, 24-37.

12. Tang, C.; Wan, Z.; Ng, P.; Dai, X.; Sheng, Q.; Da, C. Temporal and spatial evolution of carbon emissions and their influencing factors for tourist attractions at heritage tourist destinations. Sustainability 2019, 11, 5944. [CrossRef]

13. Su, J. Impact of tourism resource development based on low-carbon mode: A case study of Guizhou ethnic areas. Ecol. Process. 2019, 8, 21. [CrossRef]

14. UNWTO. World Tourism Barometer; UNWTO: Madrid, Spain, 2021; Volume 19.

15. Vanzetti, D. Peters Ralf COVID-19 and Tourism: An Update-Assessing the Economic Consequences 2021. Available online: https://unctad.org/system/files/official-document/ditcinf2021d3_en_0.pdf (accessed on 12 January 2022).

16. UNWTO. Tourism and COVID-19-Unprecedented Economic Impacts. Available online: https:/ / www.unwto.org/tourism-andcovid-19-unprecedented-economic-impacts (accessed on 30 December 2021).

17. Obersteiner, G.; Gollnow, S.; Eriksson, M. Carbon Footprint Reduction Potential of Waste Management Strategies in Tourism. Environ. Dev. 2021, 39, 100617. [CrossRef] [PubMed]

18. Martins, A.M.; Cró, S. The Impact of Tourism on Solid Waste Generation and Management Cost in Madeira Island for the Period 1996-2018. Sustainability 2021, 13, 5238. [CrossRef]

19. Larasti, A.K. Environmental Impacts Management of the Coachella Valley Music and Arts Festival. Tour. J. Pariwisata 2020, 2, 56. [CrossRef]

20. Widyarsana, I.M.W.; Agustina, E. Waste Management Study In The Archipelago Tourism Area (Case Study: Nusa Penida District, Bali Province, Indonesia). E3S Web Conf. 2020, 148, 05002. [CrossRef]

21. Muñoz, E.; Navia, R. Waste Management in Touristic Regions. Waste Manag. Res. 2015, 33, 593-594. [CrossRef]

22. Wu, W.; Zhang, X.; Yang, Z.; Wall, G.; Wang, F. Creating a low carbon tourism community by public cognition, intention and behaviour change analysisa case study of a heritage site (Tianshan Tianchi, China). Open Geosci. 2017, 9, 197-210. [CrossRef]

23. Röck, M.; Saade, M.R.M.; Balouktsi, M.; Rasmussen, F.N.; Birgisdottir, H.; Frischknecht, R.; Habert, G.; Lützkendorf, T.; Passer, A. Embodied GHG Emissions of Buildings-The Hidden Challenge for Effective Climate Change Mitigation. Appl. Energy 2020, 258, 114107. [CrossRef]

24. UN Environment Programme 2020 Global Status Report for Buildings and Construction. Glob. Status Rep. 2020, 2020, 20-24.

25. Shang, M.; Geng, H. A study on Carbon Emission Calculation of Residential Buildings Based on Whole Life Cycle Evaluation. E3S Web Conf. 2021, 261. [CrossRef]

26. Bowyer, J. Carbon Implications of Building Materials Selection; The Wood Products Council: Minneapolis, MA, USA, 2015.

27. Sari, D.; Rizki, M.; Nathania, B.; Ahmad, M.; Gunawam Gan, P.; Noor, N. Indonesia Zero Emissions Application (EMISI): Methodology for Calculating Individual Emissions from Food, Clothing, Electricity Consumption, and Solid Waste. World Resour. Inst. 2021. [CrossRef]

28. Nurhadi, M.; Budiarti, R. Timbunan Sampah Harian Pada Rumah Tangga; Bintari Foundation: Semarang, Indonesia, 2020. 